CARAKA: Indonesian Journal of Communications, vol. 2(1), 2021, 8-19

\title{
Interaksi Komunitas Menggunakan Fitur Fd Talk di Aplikasi Female Daily
}

\author{
https://doi.org/10.25008/caraka.v2i1.55 \\ Aulia Nur Indrayani, Rama Kertamukti \\ Universitas Islam Negeri Sunan Kalijaga - Yogyakarta
}

\begin{abstract}
New media presents a new style to meet the audience. Female Daily community has many application features for the member's space to interaction each other, such as Acne Warrior group in FD Talk, a very large number of group members generate the diverse interaction, the message feedback becomes the gap between communicant and communicator because of the large interactions. This study aims to analize the communication network by using intact network analysis on Acne Warrior Group. The Research method used qualitative and netnography methode, with netnography data collection techniques were archive, elasitation, and field notes data collected by interview, observation, and documentation, by using the help of UCINET data processing. The result of study were researched based on actor, community, and network structure level.
\end{abstract}

Keyword: Netnography, communication network analysis, new media, virtual community

ABSTRAK

Kehadiran komunitas virtual membentuk tren baru untuk berkomunikasi dan berinteraksi di ruang virtual. Dalam komunitas virtual Female Daily terdapat beberapa fitur aplikasi sebagai wadah interaksi anggota komunitas, salah satunya adalah fitur FD Talk grup Acne Warrior, anggota grup yang sangat banyak menghasilkan interaksi yang beragam, timbal balik pesan menjadi kesenjangan antara komunikator dengan komunikan karena jumlah interaksi yang banyak. Penelitian ini bertujuan untuk menganalisis jaringan komunikasi menggunakan analisis jaringan utuh di grup Acne Warrior. Jenis penelitian yang digunakan adalah kualitatif dan metodologi penelitian yang digunakan yaitu netnografi, dengan menggunakan teknik pengumpulan data netnografi yaitu data arsip, data elasitasi, dan data catatan lapangan yang dikumpulkan melalui wawancara, observasi, dan dokumentasi dengan bantuan pengolahan data UCINET dan NETDRAW. Hasil penelitian diteliti berdasarkan tingkatan aktor, kelompok, dan struktur jaringan.

Kata kunci: Netnografi, analisis jaringan komunikasi, media baru, komunitas virtual

\begin{tabular}{|l|}
\hline Aulia Nur Indrayani's email: auliaindrayani10@gmail.com \\
\hline Para penulis menyatakan tidak mempunyai konflik kepentingan dalam penelitian dan penerbitan publikasi ini. \\
\hline $\begin{array}{l}\text { Copyright @ } 2021 \text { (Aulia Nur Indrayani). } \\
\text { Licensed under the Creative Commons Attribution-NonCommercial-ShareAlike 4.0 (CC BY-SA 4.0) } \\
\text { Available at http://caraka.web.id }\end{array}$ \\
\hline Submitted: 12 April 2021, Revised: 05 May 2021, Accepted: 09 June 2021 \\
\hline
\end{tabular}




\section{PENDAHULUAN}

Akselerasi teknologi digital dan hadirnya media baru menjadikan sesuatunya mudah dicari. Media baru memberikan cara yang berbeda untuk bertemu audience, sehingga jarak dan waktu tidak lagi menjadi halangan berkomunikasi (Astuti, 2015). Melalui media baru audience tidak menerima pesan secara pasif. Mereka terhubung dengan jaringan sehingga bisa berinteraksi satu sama lain dan menyampaikan pesan (Adnan \& Iskandar, 2020). Kehadiran media baru membentuk komunitas virtual yang menjadi tren baru di ruang virtual (Muhammad \& Manalu, 2017).

Dalam komunitas virtual, sekumpulan orang yang memiliki ketertarikan sama bisa saling berinteraksi tanpa bertatap muka. Melalui komunitas virtual, pertemuan fisik bisa dilakukan secara virtual. Norma yang digunakan tentunya berbeda. Di ruang siber, netizen bernorma bebas. Interaksi di ruang siber juga berbeda. Sebelumnya masyarakat berkomunikasi secara verbal dan nonverbal, tetapi di ruang siber, komunikasi dilakukan menggunakan teks dan emoji (Belvage, 2012).

Female Daily merupakan komunitas virtual perempuan terbesar di Indonesia dengan anggota sebanyak 450 juta, membahas tentang fashion dan kencantikan. Female Daily menggunakan Web App dan Mobile sebagai media komunitas. Tujuan didirikannya Female Daily adalah memberikan kesempatan kepada perempuan dengan kesukaan serupa untuk berdiskusi di grup yang disediakan.

Famale Daily memiliki 60 grup, salah satunya grup Acne Warrior yang anggotanya memiliki latar belakang heterogen dengan permasalahan sama sehingga mereka cenderung blak-blakan membahas permasalahan mereka. Interaksi yang terjadi misalnya tentang rekomendasi produk atau meminta pendapat tentang pengalaman anggota lain saat menggunakan produk tertentu. Menurut Bungin, seseorang dapat berbagi cerita, pengalaman, bertukar informasi, pengetahuan dan lain sebagainya di dalam suatu komunitas. Tidak berbeda dengan komunitas nyata, di komunitas virtual juga terjadi interaksi sesama anggota. Masyarakat maya mengandalkan interaksi sosial dan proses sosial dalam kehidupan kelompok dan antarsesama masyarakat maya (Bungin, 2008: 161).

Interaksi di grup Acne Warrior, anggota yang bertanya jarang memberikan respon balik ketika ada anggota lain yang menjawab pertanyaan atau cerita tentang pengalamannya. Komunitas ini juga tidak membatasi jumlah orang bertanya. Chat di grup tidak hilang dalam jangka waktu tertentu sehingga banyak pertanyaan berulang, menyebabkan anggota malas berinteraksi di kelas Acne Warrior. Dalam kaitan itulah penelitian ini menggunakan metodologi netnografi untuk mengetahui jaringan interaksi virtual anggota komunitas melalui percakapan di grup Acne Warrior.

\section{KERANGKA TEORI}

Littlejohn \& Foss (2009) mengatakan, jaringan adalah susunan sosial yang diciptakan oleh komunikasi antarindividu atau kelompok. Dalam pandangan ini dipahami, tidak ada seorang pun yang tidak berkomunikasi dalam sebuah kelompok atau komunitas tertentu. Saat manusia saling berkomunikasi, dengan sendirinya tercipta mata rantai yang merupakan sebuah pola jaringan. Pola hubungan dalam jaringan menghasilkan struktur tertentu dan setiap aktor menempati posisi tertentu dalam struktur jaringan.

Pada teori jaringan, aktor bisa saja individu ataupun kelompok, karena fokus teori jaringan pada struktur mikro hingga makro. Gagasan struktural dasar dari teori jaringan komunikasi adalah keterkaitan (connectedness) yaitu gagasan bahwa ada pola komunikasi yang cukup stabil antarindividu (Littlejohn \& Foss, 2009). Individu-individu yang saling berkomunikasi terhubung ke dalam kelompok-kelompok yang selanjutnya saling terhubung dalam keseluruhan jaringan melalui pesan atau arus informasi.

Ketertarikan dalam jaringan dapat berupa; pertama, jaringan pribadi (personal networks) yaitu hubungan dimana setiap orang memiliki susunan hubungan yang khusus dengan orang lain dalam 
organisasi. Kedua, jaringan kelompok (group networks) yaitu bahwa organisasi merupakan kumpulan dari beberapa kelompok dan kelompok-kelompok tersebut saling berkomunikasi dengan kelompok lain. Ketiga, jaringan organisasi (organizational networks) yaitu hubungan komunikasi yang terjadi antara beberapa organisasi. Keempat adalah jaringan global (global networks) merupakan sebuah jaringan kompleks.

Hubungan antara individu dengan individu lainnya, kelompok dengan kelompok lainnya dan organisasi dengan organisasi lainnya terdapat mata rantai (link). Mata rantai dapat mendefinisikan sebuah peranan jaringan (network role) tertentu, yang berarti mereka menghubungkan kelompokkelompok dalam cara-cara tertentu. Peran jaringan menentukan cara bagaimana aktor sosial (individu, kelompok, atau organisasi) terhubung satu sama lain. Selain mempertimbangkan karakteristik dari jaringan secara keseluruhan (isi, modus, dan kepadatan/density) dan mempertimbangkan keterhubungan jaringan (strength, symmetry, and multiplexity) kemunculan jaringan komunikasi juga harus mempertimbangkan peranan jaringan.

Ada tujuh peranan aktor dalam suatu jaringan komunikasi Pace \& Faules (2002), yaitu: (1) Klik (clique), merupakan sekelompok individu yang memiliki sedikit separuh dari kontaknya merupakan hubungan dengan anggota-anggota lainnya. Sebuah klik terbentuk bila lebih dari separuh komunikasi anggota-anggotanya adalah komunikasi sesama anggota, bila setiap anggota dihubungkan dengan semua anggota lainnya dan bila tidak ada satu hubungan pun atau seorang anggota pun yang dapat dihilangkan sehingga mengakibatkan anggota kelompok terpecah; (2) Penyendiri (isolate) mereka yang hanya melakukan sedikit bahkan tidak melakukan kontak dengan anggota kelompok lain; (3) Jembatan (bride) adalah seorang anggota klik yang memiliki sejumlah kontak yang menonjol dalam kontak antar kelompok, juga menjalin kontak dengan anggota klik lain; (4) Penghubung (liaison) adalah orang yang mengubungkan atau mengaitkan dua klik atau lebih tetapi ia bukan anggota salah satu kelompok yang dihubungkan tersebut; (5) Penjaga gawang (gate keeper) adalah orang yang secara strategis ditempatkan dalam jaringan agar dapat melakukan pengendalian atas pesan apa yang akan disebarkan melalui sistem tersebut; (6) Pemimpin pendapat (opinion leader) adalah orang tanpa jabatan formal dalam semua sistem sosial yang membimbing pendapat dan memengaruhi orang-orang dalam keputusan tersebut; (7) Kosmopolit (cosmopolite) adalah individu yang melakukan kontak dengan dunia luar, dengan individu-individu di luar organisasi.

Studi jaringan komunikasi merupakan ilmu yang bersifat multidisplin, kemunculan teori jaringan komunikasi diawali dengan adanya penjelasan mengenai jaringan sosial. Analisis jaringan sosial didefinisikan terhadap konsep-konsep kunci yang saling berhubungan sehingga analisis jaringan sosial didiskusikan bagaimana perbedaan tingkat analisisnya. Konsep pertama jaringan sosial adalah adanya entitas sosial yang saling memiliki keterhubungan (Cindoswari, 2017; Fikri et al., 2020).

Jaringan komunikasi berlandaskan dua hal utama yaitu aktor dan relasi. Menurut Eriyanto dalam (Fikri et al., 2020), aktor bisa berupa individu-individu ataupun unit sosial lainnya, aktor bisa berupa kelompok, departemen-departemen di sebuah perusahaan, agen-agen pemerintahan di dalam suatu kota atau negara. Analisis jaringan komunikasi melihat fenomena mikro bukan makro serta bertujuan untuk menggambarkan struktur komunikasi dan posisi seorang aktor dalam struktur komunikasi tersebut.

Pada analisa jaringan, proses komunikasi lebih melibatkan relasi daripada atribut karena relasi bukan hanya seorang individu tetapi merupakan sebuah ciri dalam relasi dua orang atau lebih. Dengan demikian jaringan komunikasi merupakan struktur yang dibangun berdasarkan relasi komunikasi. 
Jaringan komunikasi menjelaskan beberapa konsep seperti jaringan, keterhubungan, hemofili, dyad, dan kebersamaan serta keseimbangan. Prinsip-prinsip teori jaringan menurut Ritzer (2003) dalam (Ratna, 2018; Utami, 2018) adalah ikatan antar aktor biasanya simetris, aktor saling bertukar pesan berbeda dengan intensitas makin besar dan makin kecil, terstrukturnya ikatan sosial menimbulkan berbagai jenis jaringan non acak, kelompok jaringan menyebabkan timbulnya hubungan silang antara kelompok jaringan maupun antar individu, ikatan asimetris dalam jaringan menimbulkan tidak meratanya distribusi sumber daya, distribusi yang tidak merata menimbulkan kerjasama maupun kompetisi.

\section{Jaringan Komunikasi Kelompok}

Dalam menganalisis jaringan kelompok menurut Rogers dan Kincaid, yaitu (Sulistiawati, 2018): (1) Terdapat komponen utama mengidentifikasi sejumlah klik yang ada di dalam suatu sistem serta menentukan bagaimana sejumlah sub struktural ini memengaruhi komunikasi individu di dalam organisasi;(2) Mengidentifikasi peranan komunikasi khusus yang dimainkan oleh individu-individu yang bertindak sebagai opinion leader, cosmopolite, gate keepers, liaisons, bridges dan isolates; (3) Mengukur berbagai indeks struktural yang ada dalam jaringan komunikasi diantaranya tingkat keterhubungan dan keterbukaan sistem baik bagi individu maupun bagi sistem secara keseluruhan.

Rogers dan Kincaid (1981) lebih lanjut mengemukakan, terdapat sejumlah indikator dalam menganalisis jaringan komunikasi pada tingkat klik/kelompok, antara lain: (1) tingkat keterkaitan klik (clique connectedness) yang dilihat dari derajat keeratan hubungan anggota yang satu dengan anggota lainnya dalam suatu jaringan; (2) keragaman klik (clique diversity) yang ditunjukkan dari banyaknya hubungan komunikasi yang terjadi antarjaringan; (3) kekompakan klik (clique integration) yakni keadaan dimana suatu anggota dalam jaringan dapat berhubungan dengan anggota lainnya yang ditunjukkan dengan langkah-langkah hubungan komunikasi; (4) keterbukaan klik (clique openness) yakni tingkat keterbukaan hubungan anggota-anggota dalam suatu klik terhadap individu lain yang berada di luar klik tersebut di dalam suatu jaringan komunikasi (Sulistiawati, 2018).

Sementara itu, media baru menurut Denis McQuail adalah perangkat teknologi elektronik yang berbeda dengan penggunaan yang berbeda pula. Media elektronik baru ini mencakup beberapa sistem teknologi seperti: sistem transmisi, sistem miniaturisasi, sistem penyimpanan dan pencarian informasi, sistem penyajian gambar, dan sistem pengendalian (McQuail, 1987; Wallace et al., 2018), bahkan seringkali juga menggunakan bahasa-bahasa symbol. Simbolisme merupakan kunci kehidupan mental khas manusia dan melebihi tingkatan hewani belaka (Kertamukti, 2013).

Media baru dikelompokkan menjadi empat ketegori. Pertama, media komunikasi interpersonal seperti telepon, handphone, dan email. Kedua, media bermain interaktif seperti komputer, videogame, permainan dalam internet. Ketiga, media pencarian informasi yang berupa portal. Keempat, media partisipasi kolektif seperti penggunaan internet untuk berbagi dan pertukaran informasi, pendapat, pengalaman dan menjalin melalui komputer dimana penggunaannya tidak semata-mata untuk alat namun juga dapat menimbulkan afeksi dan emosional.

\section{Komunitas Virtual}

Kozinets (2010) berusaha mengembangkan pengelompokkan komunitas online. Ada asumsi yang memandang bahwa tata perilaku hingga kultural ditentukan oleh ruang hidupnya. Jika hal ini diterapkan pada ranah maya internet, maka bentuk aplikasi yang akan menentukan cara pengguna komunitas sampai dengan pembentukan kultur yang dimiliki oleh kelompok pengguna internet 
(Pratama. 2017).

Kozinets membagi kategori komunitas online berdasarkan aplikasi yang digunakan, menurutnya ada enam bentuk aplikasi yang menjadi medium interaksi yang memungkinkan manusia membangun komunitas di internet, yaitu Mailing-list, Blog, internet forum, wikis, permainan online, dan social networking service. Sarana-sarana tersebut kemudian berkembang menjadi ranah bernaung penggunanya mengembangkan komunitas dan kultur (Pratama, 2017).

Peran-peran anggota kelompok dalam komunitas virtual sama seperti kelompok pada umumnya. Bales (Littlejohn \& Foss, 2009) menyebutkan, dalam kelompok setiap individu memiliki peran sebagai penanya informasi, penanya opini, peminta saran, pemberi saran, pemberi opini, dan pemberi informasi.

Menurut Jasmadi ada empat karakteristik komunitas virtual yaitu: (1) Motif, komunitas virtual dibagi menjadi tiga motif yaitu motif untuk menjalin hubungan antar manusia, motif untuk mendapatkan informasi, dan motif untuk mengadakan transaksi; (2) Kardinilitas, komunitas virtual bisa bersifat interaksi satu ke satu, satu ke banyak dan banyak ke banyak. Kardinilitas menggambarkan siapa yang mengontrol proses pertukaran informasi; (3) Isi, komunitas virtual berasal dari individu-individu yang berada didalamnya berupa diskusi-diskusi online dan pembuatan halaman web (blog) dari individu-individu itu, bisa juga berasal dari penyedia layanan komunitas dan bersifat tradisional; (4) Otonomi, memiliki arti apakah komunitas virtual itu berdiri sendiri atau dimiliki bersama oleh anggota komunitas dan memiliki aturan yang telah disepakati bersama antar anggota komunitas itu.

\section{METODOLOGI}

Penelitian ini merupakan penelitian kualitatif yang bertujuan untuk menjelaskan fenomena mendalam melalui pengumpulan data. Metode penelitian yang digunakan adalah netnografi. Metode netnografi adalah metode yang digunakan untuk menganalisis percakapan dan interaksi di dunia virtual. Netnografi juga bisa didefinisikan sebagai metodolgi riset kualitatif yang mengadaptasi teknik riset etnografi untuk mempelajari budaya dan komunitas yang terjadi dalam komunikasi termediasi komputer atau computer-mediated communications. (Nasrullah, 2017)

Subjek penelitian menggunakan teknik purposive sampling, peneliti menentukan kriteria khusus untuk subjek yang diteliti, yaitu anggota komunitas yang berdiskusi di grup Acne Warrior dengan urutan filter Most Talk dan Popular dengan anggota memiliki beauty points minimal Level Beauty Savvy (tingkat keaktifan keempat) sampai Beauty Goddess (tingkat keaktifan kesembilan), anggota Female Daily dengan rentan usia 19-24 dan 25-29 tahun. Objek dalam penelitian ini adalah jaringan interaksi anggota komunitas di grup Acne Warrior fitur FD Talk di aplikasi Female Daily.

Teknik pengumpulan data dalam netnografi mencakup tiga jenis data yang berbeda, yaitu data arsip, data elisitasi, dan data catatan lapangan (Kozinets, 2010), peneliti mengkategorikannya menjadi wawancara, observasi partisipan, dan dokumentasi yang dibantu menggunakan UCINET dan NETDRAW untuk melakukan observasi. Pada penelitian ini, analisis data fokus pada analisis jaringan utuh (Complate Network Analysist) mulai dari tingkat aktor, kelompok, dan struktur jaringan.

\section{HASIL PENELITIAN}

Komunitas Female Daily yang memiliki banyak anggota dan grup diskusi seperti grup Acne Warrior, peneliti menemukan bentuk jaringan dan budaya siber budaya siber yang diartikan sebagai sebuah perkumpulan dari aktivitas masyarakat yang membentuk pola dan keyakinan di komunitas virtual Female Daily. Dalam analisis jaringan yang dilakukan di grup Acne Warrior data 
informan dari hasil wawancara dan observasi diolah menggunakan aplikasi UCINET dengan ketentuan kepadatan jaringan komunikasi berkisar 0 sampai 1.

Jika nilai kepadatan jaringan 1 maka kepadatan struktur jaringan dinilai padat, begitu pula sebaliknya jika nilai kepadatan jaringan komunikasi mendekati angka 0 maka struktur jaringan komunikasinya tidak padat (Fikri et al., 2020). Peneliti mengkategorikan nilai 0 bagi anggota grup yang sama sekali tidak pernah berinteraksi di grup Acne Warrior dengan anggota yang dipilih, nilai 1 bagi akun terdekat anggota grup dan yang pernah berinteraksi di grup Acne Warrior dengan anggota grup yang dipilih (dihitung minimal satu kali menjawab topik berdasarkan hasil observasi peneliti).

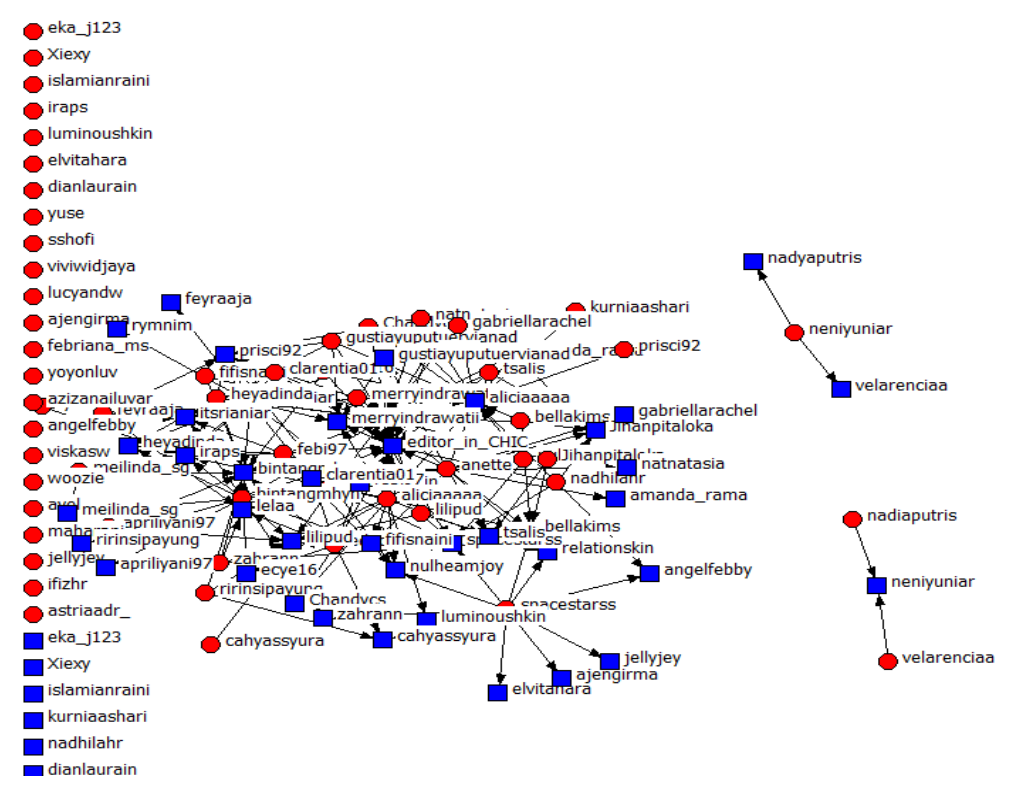

Gambar 1. Grafik sosiogram sebagai sumber informasi di grup Acne Warrior

Setelah mendapatkan data sosiometri maka selanjutnya adalah membuat grafik sosiogram untuk mengetahui aktor yang memiliki peranan penting dan dianggap sebagai sumber informasi atau akun terdekat bagi aktor lain di grup Acne Warrior, yaitu seperti akun @anette, @aliciaaaa, @bintangmhyn, dan @editor_in_CHIC.Sedangkan anggota lain, berinteraksi di grup Acne Warrior tapi tidak sepadat empat akun tersebut. Melalui grafik sosiogram juga akan terlihat individu yang berinteraksi di grup Acne Warrior dan terlihat jaringan komunikasi yang berjalan ke dalam atau keluar.

Berdasarkan grafik sosiogram pada Gambar 1, jaringan komunikasi di grup Acne Warrior terdapat klik yang saling berinteraksi dengan anggota lain, klik berupa anggota yang berinteraksi dengan membuat sub topik atau membalas sebuah topik di grup Acne Warrior saat anggota lain saat membuat topik baru. Keterangan warna biru menandakan akun tersebut dipilih untuk dijawab topiknya oleh akun warna merah, dan akun warna merah memilih akun berwarna biru sebagai akun terdekat atau akun panutannya.

Hubungan klik bisa dilihat langsung melalui observasi pada Gambar 1, yaitu akun @anette berinteraksi dengan 28 orang anggota aktif grup dengan membuat dan membalas topik yang dibuat oleh 60 anggota yang dipilih peneliti melalui observassi partisipatoris (memilih 13 akun dan dipilih 15 akun). Selanjutnya akun @aliciaaaaa berinteraksi dengan 26 anggota aktif grup (memilih 12 akun anggota dan dipilih 14 akun anggota).

Interaksi Komunitas Menggunakan Fitur Fd Talk di Aplikasi Female Daily (Aulia Nur Andriyani, Rama Kertamukti) 
Kemudian, akun @bintangmhyn berinteraksi dengan 24 anggota grup (memilih 13 akun anggota dan dipilih 11 akun anggota). Dan akun @editor_in_CHIC berinteraksi dengan 17 anggota grup (memilih sembilan akun anggota grup dan dipilih oleh 8 akun anggota). Sedangkan beberapa akun seperti @spacestarss, @nulheamjoy, @itsrianiar, @jihanpitaloka, @lelaa, @lilipud, @merryindrawatii, @heyadinda, @fifisnaini, @tsalis, @relationskin, @irapsr, @clarentia01, @febi97, @ecye16, @bellakims, @ririnsipayung, dan @zahrann merupakan anggota yang cukup aktif membuat topik di grup Acne Warrior namun tidak begitu aktif membalas topik dari anggota lain. Sehingga jaringan komunikasinya lebih longgar daripada keempat akun sebelumnya yang memiliki jaringan sangat padat. Sisanya merupakan anggota aktif grup Acne Warrior memiliki jaringan yang longgar karena interaksi yang dilakukan tidak sesering delapan belas akun di atas.

\section{Interaksi Aktor di Grup Acne Warrior}

Setiap anggota memiliki kesempatan yang sama untuk berinteraksi dengan aktor lain di grup tersebut yang dikembalikan sesuai dengan kebutuhan aktor. Interaksi yang terjadi di grup Acne Warrior diawali dengan mengangkat topik menggunakan fitur Add Topic dengan memberikan judul, deskprisi, dan menandai (tagging) yang ada di aplikasi Female Daily atau menjawab topik dengan fitur reply atau kemudian mengangkat sub topik baru di kolom reply agar diskusi terus berjalan di satu topik yang sama.

Interaksi di grup Acne Warrior garis besar temanya membicarakan seputar jerawat, baik segi produk skincare yang digunakan, curhat jerawat yang dihadapi, review produk, meminta dan berbagai tips dan trik saat berjerawat, konidisi emosional, pandagan sosial, dan masih banyak lagi topik seputar jerawat yang diangkat anggota grup Acne Warrior.

Partisipasi aktor menentukan diskusi akan berjalan dua arah atau berhenti sampai mendapatkan respon pertama. Dalam analisis jaringan pada tingkatan aktor merujuk pada pendapat Prel (2012) yang mengemukakan tiga indikator dalam jaringan komunikasi tingkat individu yang akan diuraikan berdasarkan temuan di lapangan, yaitu (Sulistiawati, 2018):

Sentralitas Kedekatan. Sentralitas kedekatan menunjukkan seberapa dekat aktor dengan semua aktor lain dalam jaringan dengan menggambarkan berapa langkah atau jalur seorang aktor bisa dihubungi atau menghubungi aktor lain dalam jaringan (Eriyanto, 2014: 168). Ukurannya adalah langkah terpendek yang dibutuhkan oleh aktor untuk menghubungi atau dihubungi oleh aktor lain.

Relasi pada sentralitas kedekatan adalah directed atau mempunyai arah outcloseness dan incloseness. Dimana outcloseness adalah aktor berperan sebagai subjek yang menghubungi aktor lain, memberikan informasi, mencari informasi. Sedangkan, Incloseness adalah aktor yang menjadi objek untuk dihubungi oleh aktor lain, diberi informasi, diberi tahu, dan diberi arahan. Dalam relasi sentralitas kedekatan, tingkat kedekatan ini menunjukkan jumlah langkah yang harus ditempuh oleh individu dalam menghubungi lainnya di dalam sistem.

Pada penelitian ini, terlihat aktor dengan outcloseness dan incloseness tertinggi adalah akun @anette, @aliciaaaaa, @irapsr, @jihanpitalo-ka, @ecye16, @bintangmhyn, @luminioushkin, @itsrianiar, @relationskin, @nulheamjoy, @spacestarss, dan @chandycs. Semua aktor di atas merupakan anggota aktif grup Acne Warrior yang sudah menjadi anggota grup sejak dibuatnya grup Acne Warrior oleh Female Daily yaitu pada tahun 2020. Relasi 12 aktor di atas menjadi dekat karena permasalahan jerawat yang sedang dihadapi atau memberikan informasi bagi para Acne Fighters di grup Acne Warrior.

Sebagai komunitas virtual dengan tujuan sebagai wadah informasi dan diskusi bagi anggotanya, Female Daily yang di dalamnya terdapat grup Acne Warrior tidak memiliki struktur 
organisasi sehingga interaksi anggota grup menyebar, sehingga anggota grup bebas berinteraksi dan tidak ada batasan interaksi kecuali batasan topik karena grup Acne Warrior digunakan oleh anggota komunitas Female Daily untuk topik yang berhubungan dengan jerawat, meskipun peneliti menemukan beberapa topik di luar permasalahan jerawat.

Menjadi anggota grup Acne Warrior dan berinteraksi di grup dengan anggota yang sangat heterogen membuat anggota grup sangat jarang yang berteman dekat dengan anggota lain di grup Acne Warrior. Berdasarkan informan yang diwawancara, yang menjawab dekat dengan anggota lain hanya empat orang dengan cara interaksi yang berbeda. Kedekatan yang dibangun karena interaksi di grup Acne Warrior yang dialami oleh @ecye16 dengan @editor_in_CHIC karena akun @editor_in_CHIC selalu membalas topik dengan sangat detail dengan durasi yang sangat sering. Sehingga keduanya tergolong memiliki kedekatan yang cukup intens di grup Acne Warrior.

Lain halnya dengan akun @nulheamjoy dengan @spacestarsss, keduanya merupakan anggota aktif di grup Acne Warrior yang sama-sama sering menceritakan masalah kulit yang sedang dialami. Kedekatan keempat akun ini diawali dari interaksi balas membalas topik yang kemudian berlanjut dan merasa lebih dekat daripada dengan anggota lain.

Sentralitas Keperantaraan. Sentralitas keperantaraan menggambarkan posisi aktor sebagai perantara dari relasi aktor satu dengan aktor lain dalam suatu jaringan (Utami, 2018). Pendapat lainnya mengatakan, sentralitas ini diartikan sebagai frekuensi dimana suatu node/ individu berada di node-node lain pada jarak yang dekat yang kemudian menghubungkan antarnode tersebut. Berkaitan dengan hal tersebut, Scott (2009) dalam Sulistiawati (2014), tingkat kebersamaan dapat diartikan sebagai tingkat ketergantungan individu terhadap individu lainnya. Dengan kata lain, tingkat kebersamaan yang tinggi menunjukkan tingginya tingkat ketergantungan individu dalam suatu sistem.

Keperantaraan aktor di grup Acne Warrior yang memiliki nilai tertinggi adalah akun @anette dengan nilai 425.698. Peranan aktor perantara ini sangat penting karena merupakan penghubung interaksi dengan anggota lain, sebagai kontrol informasi, menempati posisi menguntungkan dalam jaringan (Utami, 2018). Akun @anette merupakan akun yang sudah terverifikasi (centang merah muda) oleh Female Daily dengan level Beauty Goddest (akun teraktif di Female Daily). @anette sangat aktif membalas topik tentang rekomendasi produk dibuat mini review atau menceritakan pengalaman pribadi saat menggunakan produk tersebut sehingga pembuat topik akan merespon dan diskusi berlanjut. Anggota yang memiliki peranan sebagai penghubung di grup Acne Warrior hal ini berarti anggota penghubung tersebut bisa membuat hubungan dan menjadi penghubung anggota lain di grup Acne Warrior.

Sentralitas Eigenvektor. Sentralitas eigenvektor menggambarkan seberapa penting orang yang mempunyai jaringan dengan aktor. Secara sederhana eigenvektor melihat siapa temannya teman kita. Nilai sentralitas eigenvektor antara 0-1. Nilai mendekati 1 merupakan sentralitas eigenvektor tertinggi yang artinya aktor tersebut berhubungan dengan aktor-aktor yang mempunyai jaringan dengan aktor-aktor penting, begitu juga sebaliknya (Utami, 2018).

Pada hasil penelitian, aktor @anette dengan nilai 0,414 dan @aliciaaaaa dengan nilai 0,355 merupakan aktor dengan nilai tertinggi. Hal ini sejalan dengan pernyataan @aliciaaaaa saat diwawancarai: dia sangat aktif di grup dan senang berbagi pengalaman menghadapi jerawat dan membagikan advice soal skincare. Kepopuleran @anette dan @aliciaaaaa juga disebutkan oleh @chandycs sebagai akun panutannya dan terdekat karena sering membaca informasi tentang rekomendasi produk untuk jerawat dari kedua akun tersebut.

Selain itu, beauty point akun Female Daily menjadi salah satu faktor anggota grup memulai topik atau menyampaikan informasi dengan cara membalas topik anggota lain. Interaksi @anette 
dan @aliciaaaaa dengan anggota lain di grup Acne Warrior sangat sering, dari mulai membalas secara singkat sampai bercerita panjang lebar. Peranan mereka lebih mengarah sebagai sumber informasi seputar jerawat karena sudah berpengalaman sebelumnya dan sering mencari informasi tentang jerawat, sehingga keduanya menjadi populer karena sering berinteraksi dengan anggota lain di grup Acne Warrior, hasil lainnya yang didapatkan peneliti dari observasi bahwa di filter popular grup Acne Warrior kedua akun ini sering berinteraksi dengan anggota lain yang bertanya.

\section{Analisis Tingkat Kelompok}

Peran-peran anggota kelompok dalam komunitas virtual sama seperti kelompok pada umumnya. Bales dalam (Littlejohn \& Foss, 2009) menyebutkan, dalam kelompok setiap individu memiliki peran sebagai penanya informasi, penanya opini, peminta saran, pemberi saran, pemberi opini, dan pemberi informasi. Menurut Jasmadi ada empat karakteristik komunitas virtual yaitu motif, kardinalitas, isi, dan otonomi.

Komunitas Famel Daily ini sudah berdiri sejak 2007 oleh pendahulu Female Daily dan hingga saat ini memiliki anggota yang sangat banyak sehingga interaksi anggota hanya sebatas interaksi untuk mencari informasi, sehingga sangat jarang anggota komunitas merasa memiliki terhadap komunitas. Banyak juga anggota yang menyalurkan hobi dan minat terhadap beuaty melalui unggahan di aplikasi, seperti mengunggah hasil make-up, kondisi kulit, produk yang sedang digunakan, alat make-up, atau hasil giveaway.

Pada tingkat analisis kelompok, komponen yang terbentuk dari jaringan anggota grup Acne Warrior berdasarkan grafik sosiogram (Gambar 1) membentuk tiga sub kelompok dengan satu jaringan besar dan dua jaringan kecil yang tidak melakukan interaksi dengan anggota di jaringan besar. Analisis jaringan pada tingkat kelompok dibagi menjadi dua desain studi jaringan utuh, sebagai berikut (Utami, 2018):

Komponen. Komponen merupakan pengelompokkan aktor yang mempunyai link dengan jaringan. Komponen merupakan lawan dari isolate yaitu aktor yang tidak terhubung dengan jaringan atau aktor yang tidak mempunyai link dengan jaringan (Utami, 2018). Hasil penelitian jaringan di grup Acne Warrior memperlihatkan bahwa setiap aktor memiliki link dengan aktor lain di grup Acne Warrior meskipun ada dan tidak ada yang menyadari karena tidak memperhatikan usermane Female Daily anggota lain yang berinteraksi.

Klik. Klik adalah pengelompokan aktor dengan memasukkan semua hubungan di antara aktor yang saling berinteraksi. Klik menggambarkan bentuk relasi para aktor sehingga terlihat cara mereka berkomunikasi. Klik dapat beranggotakan 3-4 aktor. Klik mempunyai dua kekhasan yaitu sesama aktor saling terhubung dan mempunyai semua interaksi secara maksimal (Utami, 2018). Di grup Acne Warrior dengan mengambil 60 anggota untuk diuji dengan hasil terdapat 46 jumlah klik dengan klik tertinggi berjumlah lima klik dengan masing-masing beranggota empat orang.

\section{Struktur Jaringan Acne Warrior}

Analisis stuktur jaringan di grup Acne Warrior pada tingkat struktur jaringan untuk mengetahui: kepadatan jaringan, resiprositas, diameter dan jarak, dan sentralisasi.

Kepadatan. Kepadatan adalah intensitas komunikasi antaraktor dalam jaringan. Kepadatan tinggi dalam jaringan memperlihatkan antaraktor saling berinteraksi secara maksimal sedangkan kepadatan rendah memperlihatkan interaksi antaraktor dalam jaringan minim (Utami, 2018). Jika dikaitkan dengan hasil penelitian, kepadatan jaringan komunikasi di grup Acne Warrior memiliki kepadatan yang kecil, yaitu 0,047. Hal tersebut karena anggota grup Acne Warrior hanya 
berinteraksi saat ingin menanyakan atau berdiskusi seputar masalah kulit, atau menjawab topik anggota lain yang topiknya diketahui.

Resiprositas. Resiprositas yaitu hubungan timbal balik dalam kelompok. Resiprositas (reciprocity/mutuality) adalah penguraian interaksi antar aktor, apakah berlangsung searah atau dua arah (Utami, 2018). Hasil resiprositas grup Acne Warrior mendapatkan hasil dengan nilai 0,659. Hal ini menunjukkan, kebanyakan interaksi aktor berjalan dua arah. Perhitungan resiprositas menunjukan adanya ketimpangan jaringan komunikasi di grup Acne Warrior.

Hasil resiprositas yang tinggi dikarenakan anggota grup Acne Warrior memiliki peranan yang bebas untuk berdiskusi tentang jerawat dan masalah kulit lainnya di grup. Selain itu, tidak ada faktor struktural yang mempengaruhi keaktifan anggota grup karena semua anggota komunitas Female daily yang ingin bergabung menjadi anggota grup Acne Warrior bisa langsung bergabung dengan menekan tombol "Join Group", sehingga, anggota grup Acne Warrior bisa sebebas mungkin menanyakan, menjawab, dan memberi informasi kepada anggota lain, dan berlaku sebaliknya.

Diameter dan Jarak. Grup Acne Warrior mendapatkan hasil jarak 2,3. Hal ini menggambarkan 2,3 langkah yang diperlukan oleh anggota grup Acne Warrior untuk berinteraksi dengan anggota lainnya. Jarak tersebut termasuk pendek, dikarenakan interaksi yang terjadi di grup Acne Warrior berada di bawah rata-rata jarak. Grup Acne Warrior merupakan grup besar yang ada di aplikasi Female Daily yang memiliki sangat banyak anggota sehingga anggota satu sama lain jarang saling mengenal. Faktor lainnya, hasil observasi peneliti anggota grup Acne Warrior jarang memperhatikan username akun Female Daily anggota lain karena para anggota grup fokus pada pembahasan topik dalam berinteraksi meskipun terdapat fitur mention.

Sentralisasi. Sentralisasi menggambarkan pemusatan jaringan pada beberapa aktor. Hasil penelitian mendapatkan nilai hasil 0,285 yaitu sentralisasi aktor tinggi terutama pada aktor @aliciaaaa, anggota biasa di grup Acne Warrior yang sangat aktif dalam menjawab topik anggota lain di grup Acne Warrior. Keaktifan akun @aliciaaaa ini menjadikannya menjadi akun yang sering terlihat di grup Acne Warrior oleh anggota lain.

Dapat disimpulkan, interaksi anggota grup Acne Warrior tidak terlalu tinggi namun mencerminkan tingginya kualitas interaksi anggota di grup Acne Warrior. Hal ini disebabkan karena setiap anggota memiliki kesempatan yang sama untuk berpartisipasi di grup Acne Warrior baik untuk membuat topik atau menjawab topik sampai terjadinya diskusi, kesetaraan posisi aktor (tanpa struktural) menjadikan peranan aktor yang menonjol dihasilkan dari keaktifan mereka sendiri di dalam grup.

Kepadatan jaringan dapat ditingkatkan melalui solidaritas yang kuat serta rasa memiliki untuk menghidupkan grup menjadi media informasi dan sebagai wadah diskusi anggota tentang permasalahan jerawat. Jika perasaan saling membantu ditegaskan dalam bentuk aksi nyata, maka hubungan baru dengan pola interaksi tinggi akan terbentuk (Scott, 2000). Hal tersebut berkaitan dengan prinsip teori jaringan bahwa aktor saling bertukar pesan sehingga ikatan aktor bersifat simetris atau dua arah dan menghasilkan jaringan nonacak.

Berdasarkan pemaparan di atas, terlepas dari Bahasa yang digunakan oleh para anggota yang diteliti di grup Acne Warrior saat berinteraksi dengan anggota lainnya, para anggota aktif bisa berinteraksi di dalam grup besar dan membentuk jaringan komunikasi. Keenam puluh anggota aktif cenderung menjadi sumber informasi berdasarkan hasil pengalamannya masing-masing.

Informan menuturkan, interaksi di grup Acne Warrior bisa menjawab masalah yang sedang dihadapi. Informasi berdasarkan pengalaman pribadi lebih sesuai karena kondisi yang pernah dialami sama, terutama komunikasi yang berjalan dua arah maka informasi yang didapat juga buka sebatas saran. Namun, karena komunitas Female Daily sangat besar dengan grup Acne Warrior 
yang sangat besar juga, jadi anggotanya sulit merasakan rasa memiliki terhadap komunitas, bahkan sesama anggota yang sering berinteraksi pun tidak saling mengenal satu sama lain.

\section{KESIMPULAN}

Temuan peneliti di grup Acne Warrior pada Aplikasi Female Daily adalah interaksi yang terjadi dijabarkan melalui tingkat aktor, kelompok, dan struktur sosial. Interaksi pada tingkat aktor menunjukkan, setiap individu di grup Acne Warrior memiliki kesempatan sama untuk berinteraksi dengan anggota lain dengan cara masing-masing. Ada yang sangat singkat memberikan saran dan informasi, ada yang hanya menceritakan pengalaman pribadi, sangat detail dalam menyampaikan pesan, atau hanya bercanda di kolom reply topik anggota lain.

Pada analisis tingkat kelompok terlihat, setiap anggota memiliki link dengan anggota lain, meskipun ada yang menyadari dan ada juga yang tidak menyadari interaksinya, dan tampak tidak ada anggota grup yang tidak memiliki link satu pun dengan anggota lain karena interaksinya lewat topik yang dibuat, dan setiap topik minimal dibalas oleh satu orang.

Pada analisis tingkat struktur jaringan memperlihatkan, grup Acne Warrior memiliki kepadatan jaringan yang rendah, resiprositas yang dihasilkan tinggi dengan jarak dan diameter pendek, namun memiliki sentralitas rendah. Interaksi yang terjadi di grup Acne Warrior menyebar karena kesetaraan posisi aktor (tanpa struktural) sehingga menjadikan peranan aktor yang menonjol dihasilkan dari keaktifan mereka sendiri di dalam grup baik sebagai sumber informasi atau sebagai pencari informasi.

Interaksi yang berjalan tanpa struktural di grup Acne Warrior dan banyaknya anggota tidak saling mengenal memperlihatkan kepadatan jaringan yang rendah, kemudian tidak adanya pemusatan di grup Acne Warrior sehingga setiap aktor bisa berinteraksi dengan anggota grup sesuai dengan informasi yang dibutuhkan atau informasi yang ingin dibagikan. Hasil penelitian ini menggambarkan anggota aktif grup Acne Warrior yang berinteraksi membentuk sebuah jaringan komunikasi, namun diperlukan pengikat bagi anggota grup agar jaringan komunikasi di dalam grup tetap stabil dan sesuai dengan tujuan komunitas Female Daily membuat grup ini.

\section{DAFTAR PUSTAKA}

Adnan, I., \& Iskandar, D. (2020). Studi Netnografi Belajar Membuat Podcast pada Komunitas The Podcasters Di Media Social Discord. Jurnal Syntax Transformation, 1(9), 619-623.

Astuti, Y. D. (2015). Dari Simulasi Realitas Sosial Hingga Hiper-Realitas Visual: Tinjauan Komunikasi Virtual Melalui Sosial Media di Cyberspace. Profetik, 8(2), 15-26.

Belvage, R. H. (2012). Budaya Manusia Digital. Jurnal RANAH, 2(01).

Bungin, B. (2008). Sosiologi Komunikasi (Teori, Paradigma, dan Discourse Teknologi Komunikasi di Masyarakat). Jakarta: Kencana Prenada Media Group.

Costello, Leesa. dkk. (2017). Netnography: Range of Practices, Misperceptions, and Missed Opportunities. International Journal of Qualitative Methods. Hal 1-12.

Ekaputri, D Ekasarah. DKK. (2020). Literasi Informasi Kecantikan di Kalangan Pengguna Female Daily Network. BACA: Jurnal Dokumentasi dan Informasi. Hal 111-121.

Engelrika. (2018). Pola Komunikasi di Media Online (Studi Netnografi Komunikasi Youth Proactive di Media Facebook dan Instagram). Skripsi. Fakultas Ilmu Komunikasi. Universitas Multimedia Nusantara, Tangerang.

Erikson, Henrik \& Erikson, Martin Salmann. LiLEDDA: A Six-Step Forum-Based Netnographic Research Method for Nursing science. APORIA. Hal 6-18.

Eriyanto. (2014). Analisis Jaringan Komunikasi. Jakarta: Kencana. 
Evelina, W Lidya. (2018). Komunitas adalah Pesan: Studi Netnografi Virtual di Situs Wisata TripAdvisor. Warta ISKI Hal 65-74.

Fikri, M., Rahmanto, A., \& Suparno, B. A. (2020). Jaringan Komunikasi tentang Isu Polemik Audisi Perkumpulan Bulutangkis Djarum tahun 2019 di Twitter. Jurnal IImu Komunikasi, 18(2), 194. https://doi.org/10.31315/jik.v18i2.3552

Griffini, Em. (2012). First Look at Communication Theory, 8th Edition. New York: McGraw Hill.

Hapsari, R Dwi. (2016). Peran Jaringan Komunikasi Dalam Gerakan Sosial untuk Pelestarian Lingkungan Hidup. Jurnal Komunikasi. Hal 25-36.

Hariatiningsih, R Laurensia dan Irwanto. (2020). Penggunaan Skincare Dan Penerapan konsep Beauty 4.0 Pada Media Sosial (Studi Netnografi Wanita Pengguna Instagram). Journal Komunikasi, Vol 11 No.2 September 2020.

Isnaini, Muhammad. dkk. (2020). Role of Communication Network in Intergroup Conflics. Jurnal Komunikasi Profetik, Hal 260-275.

Jasmadi. (2008). Membangun Komunitas Online Praktis dan Gratis. Jakarta: Elex Media.

Kozinet. R. V.(2007). Netnography: Redefined. London: SAGE Publications.

JK Sutopo. (2017). Jaringan Komunikasi tentang Inovasi Obyek dan Strategi Kelompok Pengemis di Kampung Padangan di Kota Solo. Jurnal IImu Komunikasi, 120-133.

Kriyantono, R. (2006). Teknik Praktis Riset Komunikasi. Jakarta: PT. Kencana Perdana.

Kertamukti, R. (2013). Komunikasi Simbol, Profetik Jurnal Komunikasi, 6(1), 53-66.

Littlejohn, W. S., \& Foss, A. K. (2009). Encyclopedia of Communication Theory. Journal of Chemical Information and Modeling, 53(9).

Muhammad, R., \& Manalu, S. R. (2017). Analisis Pemanfaatan Virtual Community sebagai Media Komunikasi Kelompok melalui Sosial Media. Diponegoro University.

Nasrullah, R. (2017). Peer Riview Etnografi Virtual Riset Komunikasi Budaya Sosioteknologi di Internet. Simbiosa Rekatama Media.

Nasih, M. dkk. (2020). Influencer Dan Strategi Penjualan: Studi Netnografi Pada Pengguna Jasa Selebgram Sebagai Media Promosi. Benefit: Jurnal Manajemen dan Bisnis, 135-144.

Pangestu, M. (2015). Jaringan Komunikasi di The Piano Institute Surabaya. Jurnal E-komunikasi, 112.

Purwanto, Edi \& Ihalauw, J.O.I John. (2017). Bisikan dari Balik Layar: Netnografi Strategi Bisnis Berorientasi Pasar. Journal of Business \& Applied Management, 220-233.

Ratna. (2018). Kajian Netnografi terhadap Komunitas Cyber DBC Network. Jurnal Teknologi Informasi dan Komunikasi, 54-63.

Sulistiawati, A. (2018). Analisis Jaringan Komunikasi Tingkat Kelompok dalam Gapoktan. Jurnal Sains Komunikasi dan Pengembangan Masyarakat [JSKPM], 2(2), 155-168.

Tuikka, Anne-Marie. DKK. Ethical Questions Related to Using Netnography as Research Method. Orbit Journal, 1-11.

Utami, A. B. (2018). Analisis jaringan komunikasi kelompok. MCC Conference Proceeding, 1, 1-35.

Wallace, R. dkk. (2017). Netnography: Range of Practices, Misperceptions, and Missed Opportunities. International Journal of Qualitative Methods, 1-12. 